\title{
GEOGRAPHIC ISOLATION CREATED DISTINCT PELAGE CHARACTERS IN FINLAYSON'S SQUIRREL ON ISOLATED ISLAND OFFSHORE OF THE INDOCHINA PENINSULA IN CENTRAL VIETNAM
}

\author{
Tu Ngoc Ly ${ }^{1,2}$, Son Truong Nguyen ${ }^{1,3 *}$, Masaharu Motokawa ${ }^{4}$ \\ Duong Thuy Vu ${ }^{1}$, Hai Tuan Bui ${ }^{3,5}$, Phuong Huy Dang ${ }^{1} \&$ Tatsuo Oshida ${ }^{6 *}$ \\ ${ }^{1}$ Department of Vertebrate Zoology, Institute of Ecology and Biological Resources, Vietnam \\ Academy of Science and Technology, 18 Hoang Quoc Viet Street, Hanoi, Vietnam \\ E-mails: ngoctu1890@gmail.com, https://orcid.org/0000-0002-2127-943X \\ truongsoniebr@gmail.com, https://orcid.org/0000-0003-3214-4407 \\ vuthuyduong.xd@gmail.com,https://orcid.org/0000-0001-9193-2131 \\ phuongiebr@gmail.com, https://orcid.org/0000-0002-2323-9511 \\ ${ }^{2}$ Center of Science and Technology, Hanoi Metropolitan University, 98 Duong Quang Ham, \\ Caugiay, Hanoi, Vietnam; E-mail: ngoctu1890@gmail.com, https://orcid.org//0000-0002-2127-943X \\ ${ }^{3}$ Graduate University of Science and Technology, Vietnam Academy of Science and Technology \\ 18 Hoang Quoc Viet, Caugiay, Hanoi, Vietnam \\ E-mails: tuanhai@eulipotyphla.com, https://orcid.org/0000-0003-4065-7229 \\ truongsoniebr@gmail.com, https://orcid.org/0000-0003-3214-4407 \\ ${ }^{4}$ The Kyoto University Museum, Kyoto University, Kyoto 606-8501, Japan \\ E-mail: motokawa@e23.jp,https://orcid.org/0000-0002-5359-0070 \\ ${ }^{5}$ Vietnam National Museum of Nature, Vietnam Academy of Science and Technology \\ 18 Hoang Quoc Street Hanoi, Vietnam; E-mail: tuanhai@eulipotyphla.com \\ https://orcid.org/0000-0003-4065-7229 \\ ${ }^{6}$ Laboratory of Wildlife Biology, Obihiro University of Agriculture and Veterinary Medicine \\ Obihiro 080-8555, Japan; E-mail: oshidata@obihiro.ac.jp, https://orcid.org/0000-0003-0863-9530 \\ ${ }^{*}$ Co-corresponding author
}

We found distinct pelage characters in Finlayson's squirrel (Callosciurus finlaysonii) population, which is endemic to Lao Island of the Cham Islands, located off the coast of central Vietnam. Among squirrels of the 'C. erythraeus-finlaysonii complex', which consists of all forms of $C$. erythraeus and $C$. finlaysonii, mitochondrial cytochrome- $b$ sequences show that the Lao Island squirrel forms a cluster with $C$. finlaysonii with external characters of $C$. erythraeus flavimanus, defined previously as 'C. finlaysonii morpha flavimanus'. Both squirrel forms, however, differed in pelage colour. This different colouration may have arisen from the effect of geographic isolation.

Key words: Finlayson's squirrel, Callosciurus erythraeus-finlaysonii complex, cytochrome- $b$ sequence, Vietnam, Lao Island, pelage colour. 


\section{INTRODUCTION}

Sundaland is a region of Southeast Asia that encompasses the Sunda shelf, the part of the Asian Continent that was previously submerged until the last glacial period, 110,000 to 12,000 years ago. IRwanto (2019) reported that the sea level has risen by approximately $130 \pm 10 \mathrm{~m}$ since 21,000 years ago, reaching its present level about 4,500 years ago. The Sunda shelf includes the Malay Peninsula, Sumatra, Borneo, Java, Madura, Bali, and surrounding small islands (Ben-Avraham 1973). After the sea level rose, the high peaks located near the coastlines of Sundaland became small islands near the Indochina and Malay peninsulas and large islands such as Sumatra and Borneo (Hall \& Morley 2004, Nguyen et al. 2010). Thus, the rise in sea level after the last glacial period may be the main force reasonable for the isolation of several terrestrial mammals on these newly formed islands.

Mammalian populations isolated from the mainland often evolve under different environments and may become endemic to their localities, such as the Cozumel harvest mouse (Reithrodontomys spectabilis) (PARdiñas et al. 2017) and the Amami rabbit (Pentalagus furnessi) (SCHAi-Braun \& Hackländer 2016). Recently, endemic mammalian species have also been found in small isolated islands off the Indochina Peninsula in southern Vietnam, including the Phu Quoc shrew (Crocidura phuquocensis) and Hon Khoai squirrel (Callosciurus honkhoaiensis), which were found in the Phu Quoc Island (Aвramov et al. 2007) and Hon Khoai Island (NGUYen et al. 2018), respectively. Therefore, it is possible that there are several yet to be identified mammalian forms in other coastal islands of Vietnam. Lao Island is located $15 \mathrm{~km}$ from the east coast of the Indochina Peninsula in central Vietnam, and is a part of the Cham Islands ("Cù Lao Chàm" in Vietnamese), which consist of Lao, Dai, Mo, Ong, Tai, La, Kho Me, and Kho Islands) (Fig. 1). The Cham Islands are included in the Triton Horst region of Sundaland, where the sea depth is less than $200 \mathrm{~m}$ (DAng \& Sladen 1997). During the last glacial period, this area is thought to be a part of the mainland, because of the existence of some non-volant mammals, such as rhesus monkey (Macaca mulatta).

In the present study, we compared the biological characters of the Lao Island population and mainland population. To examine the effect of geographic isolation in a short period (approximately 10,000-20,000 years), we chose Finlayson's squirrel Callosciurus finlaysonii (Horsfield, 1823). Callosciurus finlaysonii, common in Lao Island, is widely distributed in Thailand, southern Laos, southwestern Vietnam, southwestern Cambodia and southcentral Myanmar and the 16 subspecies are recognized (Koprowski et al. 2016). This species is closely related to Pallas's squirrel C. erythraeus (Pallas, 1779) (Oshida et al. 2001), which also has many various forms (e.g. Koprowski et al. 2016). Recently, BoonKHAw et al. (2017) reported that C. erythraeus and C. finlaysonii did not form each mono- 
phyletic group as respective distinct species. In addition, BALAKIREv \& RozHNov (2019) described that both species are taxonomically similar to each other, forming the 'C. erythraeus-finlaysonii complex'. In the present study, based on external characters and mitochondrial DNA sequences, we discussed the phylogeographic status of the Lao Island squirrel in C. erytheaus-finlaysonii complex, putting the effect of geographic isolation into consideration.

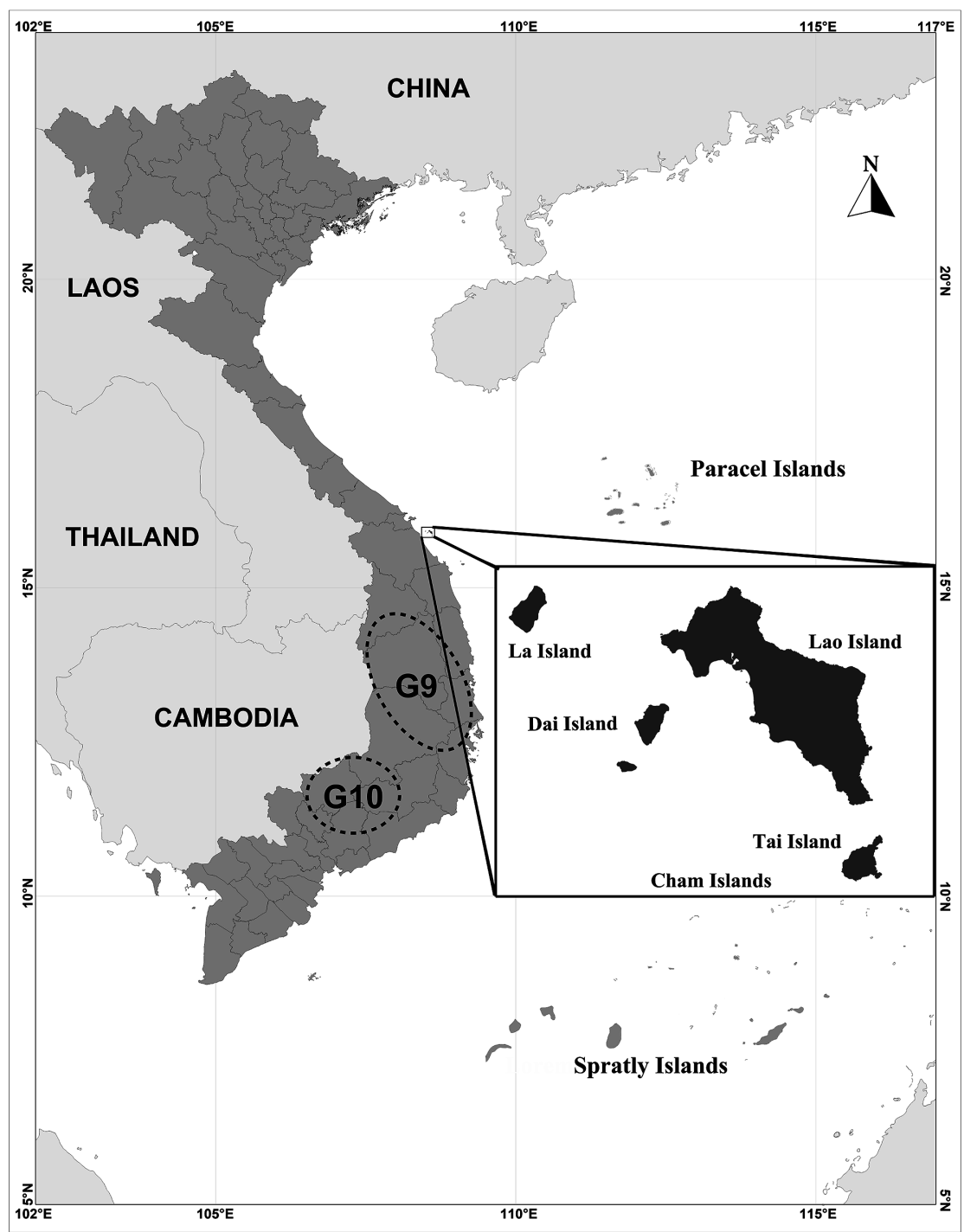

Fig. 1. Location of Lao Island, Vietnam. Dark gray areas indicate Vietnam. Dotted circles mean geographic distribution of phylogenetic groups G9 and G10 described previously by

BALAKIREv and RozhNov (2019) 


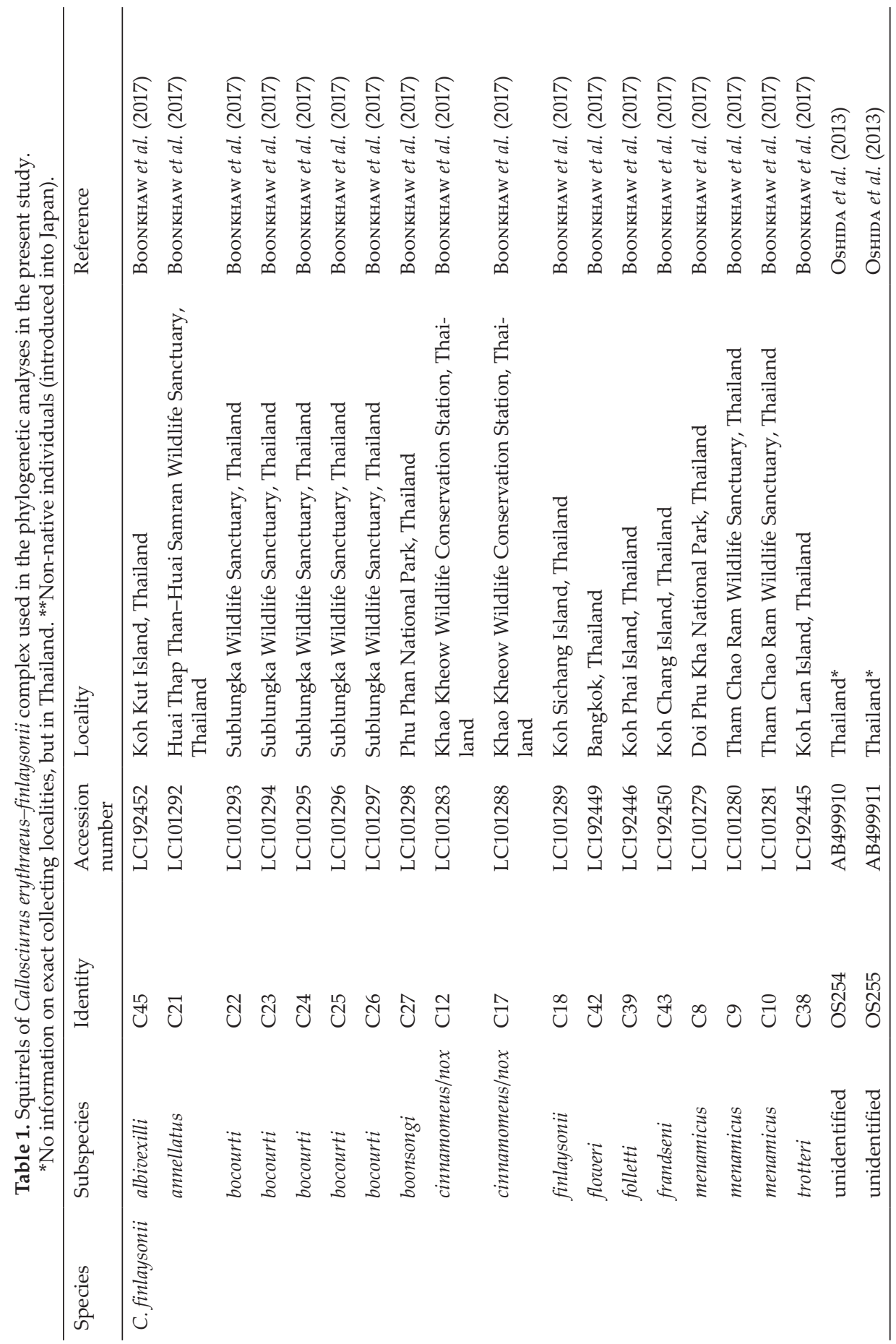




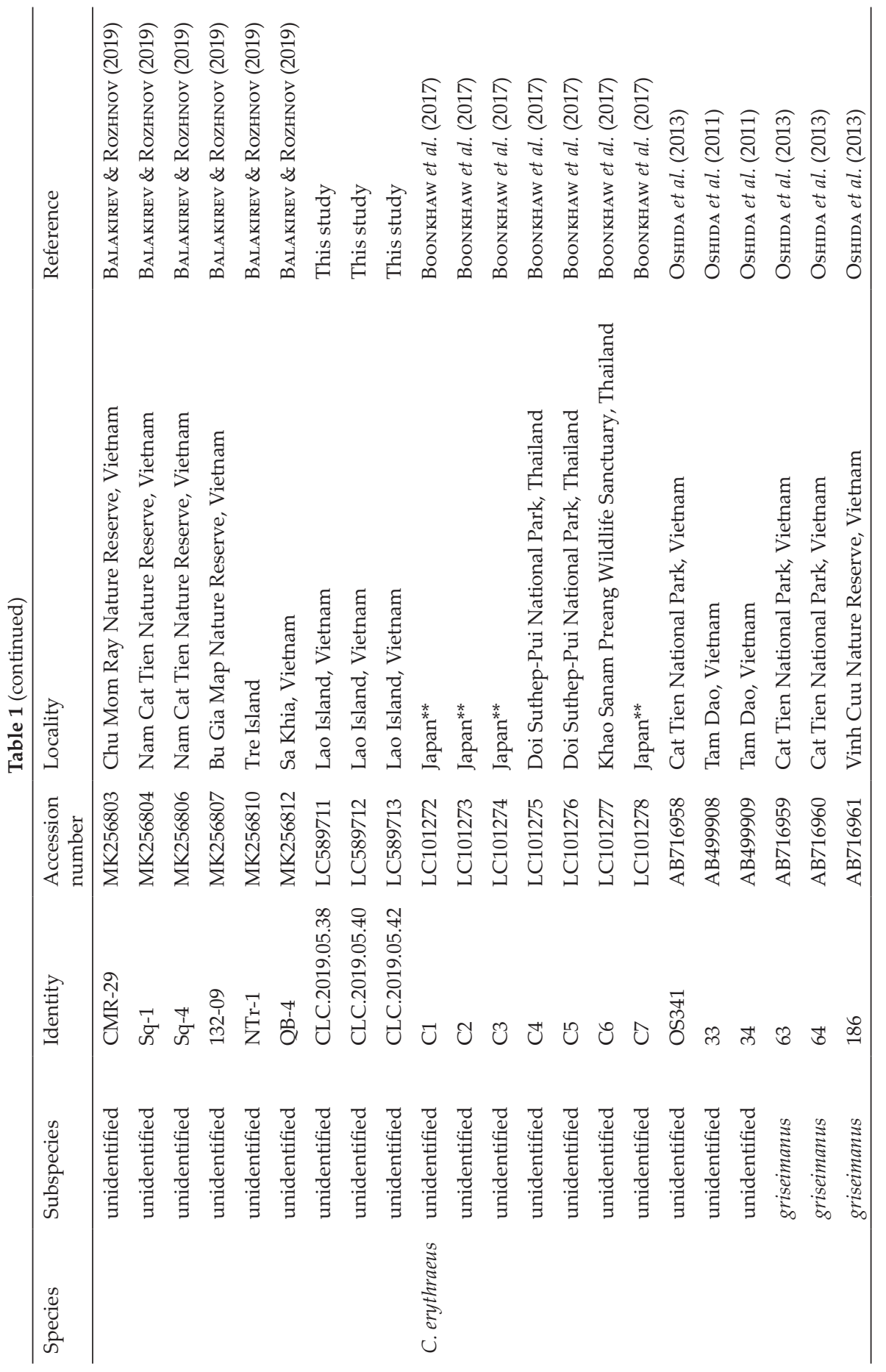




\section{MATERIALS AND METHODS}

Study site - The study was conducted in Lao Island $\left(15^{\circ} 52^{\prime}-16^{\circ} 00^{\prime} \mathrm{N}, 108^{\circ} 22^{\prime}-108^{\circ} 44^{\prime}\right.$ $\mathrm{E})$, part of the Cham Islands. The Cham Islands consisting of eight small islands, have been recognized by UNESCO as a World Biosphere Reserve since 2009 (main island shown in Fig. 1) and Lao Island with a land area of $13.17 \mathrm{~km}^{2}$ and its highest peak is $517 \mathrm{~m}$ above the sea level is the largest. Lao Island has only freshwater (Tran 2019). Lao Island is covered with a sub-tropical humid forest consisting of Brownlowia tabularis, Firmiana colorata, Aglaia macrocarpa, Dimocarpus longan ssp., Syzygium jambos, Millettia nigrescens, Heritiera angustata, Syzygium cumini, and Vitex tripinnata (Tran et al. 2018, Tran 2019). Average annual temperature, humidity, and rainfall are $25.6{ }^{\circ} \mathrm{C}, 82 \%$, and $2000 \mathrm{~mm}$, respectively (LE 2011).

Collecting - In May 2019 and July 2020, we had 300 trap days for collecting squirrels. We did not set traps every day in the two months because of weather conditions. Instead, we used cage traps $(15 \mathrm{~cm} \times 15 \mathrm{~cm} \times 25 \mathrm{~cm})$, which were set on trees about 1-2 $\mathrm{m}$ from the ground to collect seven $C$. finlaysonii specimens from Lao Island: five females (field numbers CLC.2019.05.26, CLC.2019.05.39, CLC.2019.05.40, CLC.2019.05.41, and NTS.2020.212) and two males (CLC.2019.05.38 and CLC.2019.05.42), following methods approved in the Animal Care and Use Guidelines of the American Society of Mammalogists (SikEs et al. 2016). Specimens were deposited in the Department of Vertebrate Zoology, Institute of Ecology and Biological Resources (IEBR), Vietnam Academy of Science and Technology, Hanoi, Vietnam.

External characteristics - We recorded the pelage colour of this squirrel in detail. In addition, we measured head and body length, tail length, hind foot length without a nail, and ear length using tapeline and digital calliper (NTD12-15PMX, Mitsutoyo, Japan) in millimetres $(\mathrm{mm})$ and body mass using in grams $(\mathrm{g})$.

Extraction, amplification and sequencing of DNA - Total genomic DNA was extracted from $99 \%$ ethanol-preserved muscle tissue using the DNeasy Blood \& Tissue Kit (QIAGEN K.K., Tokyo, Japan). The complete mitochondrial cytochrome- $b(C y t b)$ gene sequence (1140 bases) was amplified using polymerase chain reaction (PCR) with the primer set L14724 5'-GATATGAAAAACCATCGTTG-3' and H15910 5'-GATTTTTGGTTTAC AAGACCGAG-3'. The former and latter primers were reported by Kocher et al. (1989) and OsHidA et al. (2000), respectively. The $50 \mu \mathrm{L}$ reaction mixture contained approximately $100 \mathrm{ng}$ of genomic DNA, $0.25 \mu \mathrm{M}$ of each primer, $200 \mu \mathrm{M}$ dNTPs, $10 \mathrm{mM}$ Tris- $\mathrm{HCl}(\mathrm{pH} 8.3), 50 \mathrm{mM}$ $\mathrm{KCl}, 1.5 \mathrm{mM} \mathrm{MgCl}_{2}$, and 2.5 units of rTaq DNA polymerase (Takara, Tokyo). Amplification was performed for 35 cycles. The PCR condition for a cycle was $94{ }^{\circ} \mathrm{C}$ for $1 \mathrm{~min}, 55^{\circ} \mathrm{C}$ for 1 $\mathrm{min}$, and $72{ }^{\circ} \mathrm{C}$ for $2 \mathrm{~min}$. A final extension reaction after the 35 cycles was conducted at 72 ${ }^{\circ} \mathrm{C}$ for $10 \mathrm{~min}$. The PCR products were purified with the PCR Clean Up-M (Viogen, Taipei, Taiwan) and directly sequenced by the ABI PRISM BigDye Terminator Cycle Sequencing Ready Reaction Kit V3.1 (Applied Biosystems, CA, USA) and automated DNA sequencer (ABI PRISM 377-96 Sequencer, the ABI PRISM 3100 Genetic Analyzer, Applied Biosystems, CA, USA). For sequencing, we used the same primers used for the PCR. Purification of PCR products and sequencing were carried out by Mission Biotech Co. Ltd. (Taipei, Taiwan).

Molecular phylogenetic analyses - Sequence alignment was carried out to detect unique haplotypes using the software program DNASIS (Hitachi, Tokyo, Japan). As a result, we found three complete Cytb haplotypes of three Lao Island squirrels (CLC.2019.05.38, CLC.2019.05.40, and CLC.2019.05.42) and deposited them in the DNA Data Bank of Japan (DDBJ) (Fig. 1). Unfortunately, we did not obtain the complete Cytb sequences of the other specimens because of sample conditions.

Using 39 available partial Cytb sequences (571 bp) (Table 1), we analyzed the phylogenetic position of Lao Island squirrel among C. erythraeus-finlaysonii complex. To root 
the phylogenetic trees, we used sequences of $C$. caniceps and C. inornatus. For ML and MP analyses, we used the program MEGA version X (Kumar et al. 2018, STEChER et al. 2020). The BIC test selected the Hasegawa-Kishino-Yano model of substitution (Hasegawa et al. $1985)$ with a gamma distribution (2.85) for variable sites $(0.59)(H K Y+\Gamma+I)$ for maximum likelihood (ML) analysis. Base frequencies were estimated as $A=0.256, C=0.307, G=0.140$ and $\mathrm{T}=0.297$. The rate matrix was estimated as $\mathrm{A}-\mathrm{C}$ and $\mathrm{G}-\mathrm{C}=0.010, \mathrm{~A}-\mathrm{G}=0.131, \mathrm{~A}-\mathrm{T}$ and $\mathrm{G}-\mathrm{T}=0.009, \mathrm{~T}-\mathrm{A}=0.008, \mathrm{~T}-\mathrm{C}=0.288, \mathrm{C}-\mathrm{G}$ and $\mathrm{T}-\mathrm{G}=0.004$ and $\mathrm{G}-\mathrm{A}=0.240$. We also conducted unweighted maximum parsimony (MP) analysis. The MP tree was constructed using tree-bisection-regrafting (TBR). Additionally, we conducted neighbour-joining (NJ) using the Kimura 2-parameter method (KIMURA 1980). Bootstrapping (FELSENSTEIN 1985) was performed with 1000 replications in ML, MP, and NJ analyses for the assessment of nodal supports. Bayesian inference (BI) was performed using BEAST 1.10.4 (SuchARD et al. 2018). Bayesian analysis also used the HYK $+\Gamma+$ I substitution model and involved two runs for ten million steps, using four Markov chain Monte Carlo chains sampling every 10000 steps and a burn-in of $10 \%$. Posterior probabilities assessed the nodal support of the BI tree.

\section{RESULTS}

\section{External characters}

Photographs of one of the Lao Island squirrel is shown in Fig. 2. All specimens were almost similar in pelage colour. From the muzzle to the ears and around the cheeks were honey-yellow (dark orange) on the rostrum. Ears were dark orange (or buff) on both sides. Dorsal pelage was agouti light grey with black colour at the base and two pale brown bands in the middle. Ventral is agouti bright orange (or buff) consisting of two bands, dark greyish baseband and light orange band at middle with darker fur tip. Feet were bright orange, similar to the ventrum. The tail is agouti light brown consisting of four light bands and three dark bands. The head and body length, tail length, hind foot length, and ear length were $200.0-205.0 \mathrm{~mm}, 197.5-207.5 \mathrm{~mm}, 38.8-42.5$ $\mathrm{mm}$, and 18.5-20.2 mm, respectively. Body weight was 195-201 g.

\section{Molecular phylogenetic analysis}

The ML, MP, NJ, and BI trees of the C. erythraeus-finlaysonii complex somehow differed in branching patterns but were essentially similar to each other (Fig. 3). Within the C. erythraeus-finlaysonii complex, Lao Island squirrel formed a cluster and was closely related to $C$. finlaysonii with external characters of $C$. erythraeus flavimanus; this form was tentatively defined as ' $C$. finlaysonii morpha flavimanus (lineage G10)' by BaLAKIREv and Rozhnov (2019). Moreover, the cluster consisting of Lao Island squirrel and lineage 10 was closely related to a cluster (lineage G9) consisting of C. erythraeus griseimanus and $C$. finlaysonii with external characters of $C$. erythraeus griseimanus defined tentatively as ' $C$. finlaysonii morpha griseimanus' by BALAKIREv and RozHnov 


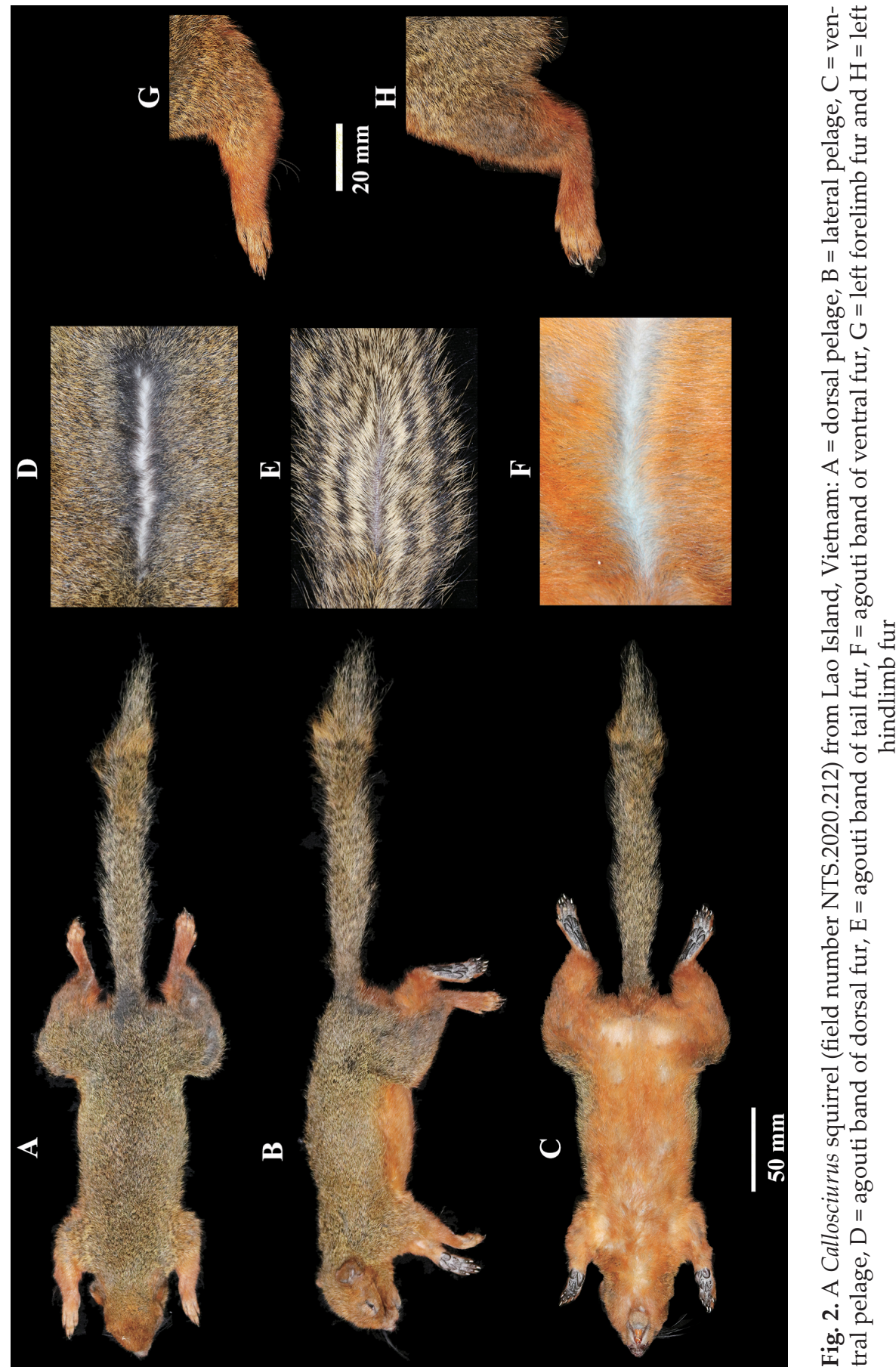


(2019). These phylogenetic relationships were supported with high bootstrap values and posterior probabilities (Fig. 3).

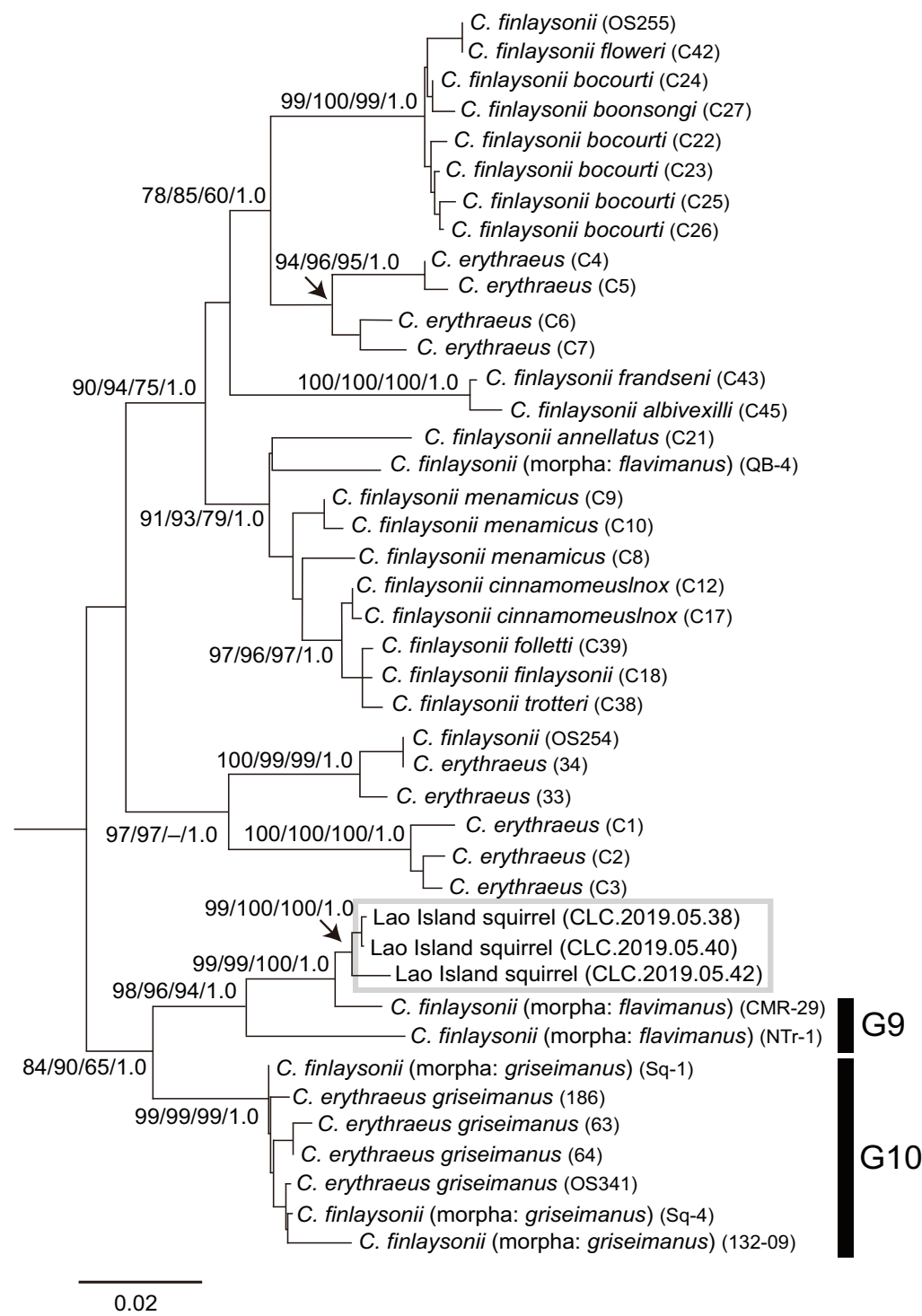

Fig. 3. Neighbour joining (NJ) phylogeny of squirrels of Callosciurus erythraeus-finlaysonii complex constructed using mitochondrial partial cytochrome- $b$ sequences under the Kimura 2-parameter-model of evolution. From left, numbers above branches represent bootstrap values from: 1000 replicates of NJ, maximum likelihood (ML) and unweighted maximum parsimony (MP) analyses, and posterior probability supports in Bayesian (BI) analysis. G9 and G10 are phylogenetic group described previously by BALAKIREv and RozHnOv (2019) 


\section{DISCUSSION}

Phylogenetic analyses showed that Lao Island squirrel and C. finlaysonii morpha flavimanus clustered together. Among C. erythraeus-finlaysonii complex, Callosciurus finlaysonii morpha flavimanus, distributed from central to southern Vietnam, is geographically most close to Lao Island squirrel. The pelage colour of Lao Island squirrel was different from those of $C$. finlaysonii morpha flavimanus. Moore \& TATE (1965) described the pelage colour of flavimanus as follows. The rostrum and fore feet are orange-yellow, and hind feet are reddish-orange. Venter varies among individuals from mars orange to burnet sienna, which extends from wrist to ankle and covers the venter except for the agouti scrotum and chin. Compared to the flavimanus, Lao Island squirrel shows a uniquely dark orange cheek and forehead. The pelage colour of Lao Island squirrel was also different from those of $C$. finlaysonii morpha griseimanus. The feet of griseimanus are white cream buff or cartridge buff (Moore \& TATE 1965), but those of Lao Island squirrel were bright orange.

After the last glacial maximum, Lao Island squirrel could be geographically isolated from the mainland population by the rise of sea level. Several researchers have reported that members of $C$. erythraeus and C. finlaysonii are easily confused taxonomically (BoonkHaw et al. 2017, BALAKIrev \& RozHnov 2019). This is because members of $C$. erythraeus and C. finlaysonii have many pelage colour variations (LeKagul \& McNeely 1988, Koprowski et al. 2016). It is difficult to explain how the pelage colour variations have been created during evolution. Lao Island squirrel was evidently different from Callosciurus finlaysonii morpha flavimanus in the colour of cheeks. The external character, such as coat colour may have evolved on the isolated island in a short time. In the Gulf of Thailand, some $C$. finlaysonii subspecies with each unique coat colour are confined to each isolated island: albivexilli, finlaysonii, folletti, frandseni, germaini, harmandi, and trotteri are distributed on Koh Kut, Koh SiChang, Koh Phai, Koh Chang, Con Son, Phu Quoc, and Koh Lan, respectively (Milne-Edwards 1877, Kloss 1915, 1916a, 1916b, 1916c, Koprowski et al. 2016). Therefore, it can be evidence that pelage colour variations of C. erythraeusfinlaysonii complex may be the result of geographic isolation. Although the isolated island populations (C. f. folletti, C. f. trotteri, and C. f. finlaysonii) are closely related to the continental populations occurring in the nearby continent (C. f. cinnamomeus and C. $f$. nox), both populations evidently differ in pelage colour; the island populations have white or beige coat colours, while C. f. cinnamomeus and C.f. nox are reddish and black, respectively (BoonKHAw et al. 2017). In addition, C. f. albivexilli and C. f. frandseni differ from the continental populations in pelage color, and also form a distinct genetic cluster (BoonkhaW et al. 2017, BALAKirev \& Rozhnov 2019). 
In C. finlaysonii, however, the individual differences of pelage colour are often observed even within subspecies (e.g. Koprowski et al. 2016). In fact, in Callosciurus squirrels, the genetic mechanism to produce pelage colour variation has not yet been studied. Therefore, in further study, we also need to clarify how the genetic mechanism contributes to creating pelage colour variation of $C$. finlaysonii.

Acknowledgements - We are grateful Sinh Van Nguyen (IEBR's director), Thinh Ngoc Van, Anh Hoa Quang Nguyen (World Wide Fund for Nature Vietnam-WWF Vietnam), Vu Van Nguyen, Thuy Hong Thi Tran, and Sanh Cong Phan (Cham Islands MPA) for supporting the expedition. We thank Bang Mai for his assistance in capturing the specimens. We thank Duy Dinh Nguyen (IEBR's staff) for designing and providing orientation maps of the study area. This research was funded by the Vietnam Academy of Science and Technology on behalf of the Program of Developing Basic Science in Chemistry, Life Sciences, Earth Sciences and Marine Science, Vietnam Academy of Science and Technology (KHCB.02/20-22). This study was partly supported by the United States Agency for International Development and World Wide Fund for Nature, Vietnam (WWF Vietnam) and the Grants-in-Aid for Scientific Research No. 18H03602 and 20H01979 from the Ministry of Education, Science, Sports, and Culture, Japan. We thank two anonymous reviewers for improving the manuscript.

\section{REFERENCES}

Abramov, A. V., Kalinin, A. A. \& Morozov, P. N. (2007): Mammal survey on Phu Quoc Island, southern Vietnam. - Mammalia 71: 40-46. https://doi.org/10.1515/MAMM.2007.001

Balakirev, A. E. \& Rozhnov, V. V. (2019): Taxonomic revision of beautiful squirrels (Callosciurus, Rodentia: Sciuridae) from the Callosciurus erythraeus/finlaysonii complex and their distribution in eastern Indochina. - Raffles Bulletin of Zoology 67: 459-489. https://doi.org/10.26107/RBZ-2019-0037

Ben-Avraham, Z. (1973): Structural framework of the Sunda Shelf and vicinity. - Massachusetts Institute of Technology and the Woods Hole Oceanographic Institution, Massachusetts, 269 pp. https://doi.org/10.1575/1912/1265

Boonkhaw, P., Prayoon, U., Kanchanasaka, B., Hayashi, F. \& Tamura, N. (2017): Colour polymorphism and genetic relationships among twelve subspecies of Callosciurus finlaysonii in Thailand. - Mammalian Biology 85: 6-13.

https://doi.org/10.1016/j.mambio.2017.02.001

Dang, H. N. \& Sladen, C. (1997): Petroleum geology of offshore Da Nang, Central Vietnam. Proceedings of the International Conference on Petroleum System of SE Asia and Australia, Indonesian Petroleum Association, Vietnam, 449-468. https://doi.org/10.29118/IPA.1004.449.460

Felsenstein, J. (1985): Confidence limits on phylogenies: an approach using the bootstrap. - Evolution 39: 783-791. https://doi.org/10.1111/j.1558-5646.1985.tb00420.x

Hasegawa, M., Kishino, H. \& Yano, T. (1985): Dating of the human-ape splitting by a molecular clock of mitochondrial DNA. - Journal of Molecular Evolution 22: 160-174. https://doi.org/10.1007/BF02101694 
Hall, R. \& Morley, C. K. (2004): Sundaland basins. Pp. 55-85. In: Clift, P., Wang, P., Kuhnt, W. \& Hayes (eds): Continent-ocean interactions within the East Asian marginal seas. American Geophysical Union, Washington DC. https://doi.org/10.1029/149GM04

Irwanto, D. (2019): Sundaland: tracing the cradle of civilizations. - Indonesia Hydro Media, Indonesia, $386 \mathrm{pp}$.

KimurA, M. (1980): A simple method for estimating evolutionary rates of base substitutions through comparative studies of nucleotide sequences. - Journal of Molecular Evolution 16:111-120. https://doi.org/10.1007/BF01731581

Kloss, C. B. (1915): On two squirrels from the inner gulf of Siam. - Journal of the Natural History Society of Siam 1: 157-162.

KLoss, C. B. (1916a): On a collection of mammals from Siam. - Journal of the Natural History Society of Siam 2: 1-32.

KLoss, C. B. (1916b): On a collection of mammals from the coast and islands of Southeast Siam. - Proceedings of the Zoological Society of London 1: 27-75.

https://doi.org/10.1111/j.1096-3642.1916.tb02008.x

KLoss, C. B. (1916c): On diagnoses of four new squirrels from Siam. - Journal of the Natural History Society of Siam 2: 178.

Kocher, T. D., Thomas, W. K., Meyer, A., Edwards, S. V., Paabo, S., Villablanca, F. X. \& Wilson, A. C. (1989): Dynamics of mitochondrial DNA evolution in animals: amplification and sequencing with conserved primers. - Proceedings of the National Academy of Sciences of USA 86: 6196-6200. https://doi.org/10.1073/pnas.86.16.6196

Koprowski, J. L., Goldstein, E. A., Bennett, K. R. \& Mendes, C. P. (2016): Family Sciuridae (tree, flying and ground squirrels, chipmunks, marmots and prairie dogs). Pp. 648-837. In: Wilson, D. E., Lacher JR, T. E. \& Mittermeier, R. A. (eds): Handbook of the mammals of the world 6: Lagomorphs and rodents I. - Lynx Edicions, Barcelona.

Kumar, S., Stecher, G., Li, M., Knyaz, C. \& Tamura, K. (2018): MEGA X: molecular evolutionary genetics analysis across computing platforms. - Molecular Biology and Evolution 33: 1870-1874. https://doi.org/10.1093/molbev/msy096

LE, V. H. (2011): Thematic reports "effects of climate change to multiple columns biodiversity". Project "Assessing the effects of climate change on species typical creatures of $\mathrm{Cu}$ Lao Cham and proposing measures conservation of endemic species, improving livelihoods for the community", Cu Lao Cham MPA management board, Vietnam, 23 pp. [in Vietnamese]

Lekagul, B. \& McNeely, J. A. (1988): Mammal of Thailand 2nd. - Darnsutha Press, Bangkok, 758 pp.

Milne-EdwARd, A. (1877): Sur quelques Mammifères et Crustacés nouveaux. - Bulletin de la Société Philomathique de Paris 11: 8-10.

Moore, J. C. \& Tate, G. H. H. (1965): A study of the diunal squirrels, Sciurinae, of the Indian and Indochinese subregions. - Chicago Natural History Museum, Chicago, 351 pp. https://doi.org/10.5962/bhl.title.2919

Nguyen, T. S., Dinh, H. V., Chan, T. D. \& Nguyen, C. H. (2010): Morpho-genetic features of Vietnam coast. - Proceedings of the 5th National Scientific Conference on Geography, Publishing House of Natural Science and Technology, Vietnam, 14 pp.

Nguyen, S. T., Oshida, T., Dang, P. H., Bui, H. T. \& Motokawa, M. (2018): A new species of squirrel (Sciuridae: Callosciurus) from an isolated island off the Indochina Peninsula in southern Vietnam. - Journal of Mammalogy 99: 813-825.

https://doi.org/10.1093/jmammal/gyy061 
Oshida, T., Lin, L-K., Masuda, R. \& Yoshida, M. C. (2000): Phylogenetic relationships among Asian species of Petaurista (Rodentia, Sciuridae) inferred from mitochondrial cytochrome b gene sequences. - Zoological Science 17: 123-128. https://org.doi/10.2108/zsj.17.123

Oshida, T., Yasuda, M., Endo, H., Hussein, N. A. \& Masuda, R. (2001): Molecular phylogeny of five squirrel species of the genus Callosciurus (Mammalia, Rodentia) inferred from cytochrome b gene sequences. - Mammalia 65: 473-482. https://org.doi/10.1515/mamm.2001.65.4.473

Oshida, T., Dang, C. N., Nguyen, S. T., Nguyen, N. X., Endo, H., Kimura, J., Sasaki, M., Hayashida, A., Takano, A., Yasuda, M. \& Hayashi, Y. (2011): Phylogenetic relationship between Callosciurus caniceps and C. inornatus (Rodentia, Sciuridae): implications for zoogeographical isolation by the Mekong River. - Italian Journal of Zoology 78: 328-335. https://doi.org/10.1080/11250003.2010.490566

Oshida, T., Dang, C. N., Nguyen, S. T., Nguyen, N. X., Endo, H., Kimura, J., Sasaki, M., Hayashida, A., Takano, A., Koyabu, D. \& Hayashi, Y. (2013): Phylogenetic position of Callosciurus erythraeus griseimanus from Vietnam in the genus Callosciurus. Mammal Study 38(1): 41-47. https://doi.org/10.3106/041.038.0105

Pardiñas, U. F. J., Myers, P., León-Paniagua L., Ordóñez Garza, N., Cook, J. A., Kryštufek, B., Haslauer, R., Bradley, R. D., Shenbrot, G. I. \& Patton, J. L. (2017): Pp. 648-832. In: Family Cricetidae (true hamsters, voles, lemmings and new world rats, and mice). Wilson, D. E., Lacher, JR T. E. \& Mittermeier, R. A. (eds): Handbook of the mammals of the world 7: Rodents II. - Lynx Edicions, Barcelona.

Schai-Braun, S. C. \& Hackländer, K. (2016): Family Leporidae (hares and rabbits). Pp. 62-148. In: Wilson, D. E., Lacher, JR T. E. \& Mittermeier, R. A. (eds): Handbook of the mammals of the world 6: Lagomorphs and rodents I. - Lynx Edicions, Barcelona.

Sikes, R. S. \& Animal Care \& Use Committee of the American Society of MammaloGISTS (2016): Guidelines of the American Society of Mammalogists for the use of wild mammals in research and education. - Journal of Mammalogy 97: 663-688. https://org.doi/10.1093/jmammal/gyw078

Stecher, G., Tamura, K. \& Kumar, S. (2020): Molecular evolutionary genetics analysis (MEGA) for macOS. - Molecular Biology and Evolution 37: 1237-1239. https://org.doi/10.1093/molbev/msz312.

Suchard, M. A., Lemey, P., Baele, G., Ayres, D. L., Drummond, A. J. \& Rambaut, A. (2018): Bayesian phylogenetic and phylodynamic data integration using BEAST 1.10. - Virus Evolution 4: vey016. https://org.doi/10.1093/ve/vey016

Tran, M. D. (2019): Results of a survey on biodiversity of terrestrial plant resources in Cu Lao Cham Biosphere Reserve in Quang Nam Province. - Scientific Report of Project: "USAID Green Annamites/ECODIT". University of Agriculture and Forestry, Hue University, Hue, Vietnam, 22 pp.

Tran, N. T., Bui, T. V., Tran, V. H., Hoang, H. Q., Le, M. V., Nguyen, H. T. T. \& Nguyen, Y. K. T. (2018): [Studying forest structure and investigating the composition of terrestrial plant species on islands in Cu Lao Cham World Biosphere Reserve]. - Journal of Forestry Science 4: 15-28. [in Vietnamese]

Received October 21, 2020, accepted July 19, 2021, published November 19, 2021 
